\title{
Tectonic map of the Ellesmerian and Eurekan deformation belts on Svalbard, North Greenland, and the Queen Elizabeth Islands (Canadian Arctic)
}

\author{
Karsten Piepjohn ${ }^{1} \cdot$ Werner von Gosen ${ }^{2} \cdot$ Franz Tessensohn $^{3} \cdot$ Lutz Reinhardt $^{1}$ • \\ William C. McClelland $^{4} \cdot$ Winfried Dallmann $^{5} \cdot$ Christoph Gaedicke $^{1}$. \\ J. Christopher Harrison ${ }^{6}$
}

Received: 7 September 2015/Accepted: 10 October 2015/Published online: 20 November 2015

(C) Springer-Verlag Berlin Heidelberg 2015

\begin{abstract}
The tectonic map presented here shows the distribution of the major post-Ellesmerian and pre-Eurekan sedimentary basins, parts of the Caledonian orogen, the Ellesmerian fold-and-thrust belt, structures of the Cenozoic Eurekan deformation, and areas affected by the Eurekan overprint. The present continental margin of North America towards the Arctic Ocean between the Queen Elizabeth Islands and Northeast Greenland and the present west margin of the Barents Shelf are characterized by the Palaeozoic Ellesmerian fold-and-thrust belt, the Cenozoic Eurekan deformation, and, in parts, the Caledonian orogen. In many areas, the structural trends of the Ellesmerian and Eurekan deformations are more or less parallel, and often, structures of the Ellesmerian orogeny are affected or reactivated by the Eurekan deformation. While the Ellesmerian fold-and-thrust belt is dominated by orthogonal compression and the formation of wide fold-and-thrust
\end{abstract}

Karsten Piepjohn

Karsten.Piepjohn@bgr.de

Werner von Gosen

werner.von.gosen@fau.de

Franz Tessensohn

ft.geopolar@t-online.de

Lutz Reinhardt

Lutz.Reinhardt@bgr.de

William C. McClelland

bill-mcclelland@uiowa.edu

Winfried Dallmann

grizzly.wkd@gmail.com

Christoph Gaedicke

Christoph.Gaedicke@bgr.de

J. Christopher Harrison

Christopher.Harrison@NRCan-RNCan.gc.ca zones on Ellesmere Island, North Greenland, and Spitsbergen, the Eurekan deformation is characterized by a complex network of regional fold-and-thrust belts (Spitsbergen, central Ellesmere Island), large distinct thrust zones (Ellesmere Island, North Greenland), and a great number of strike-slip faults (Spitsbergen, Ellesmere Island). The Ellesmerian fold-and-thrust belt was most probably related to the approach and docking of the Pearya Terrane (northernmost part of Ellesmere Island) and Spitsbergen against the north margin of Laurasia (Ellesmere Island/North Greenland) in the earliest Carboniferous. The Eurekan deformation was related to plate tectonic movements during the final break-up of Laurasia and the opening of Labrador Sea/Baffin Bay west, the Eurasian Basin north, and the Norwegian/Greenland seas east of Greenland.

1 Bundesanstalt für Geowissenschaften und Rohstoffe, Geologie der Energierohstoffe, Polargeologie, Stilleweg 2, 30655 Hannover, Germany

2 Geozentrum Nordbayern, Krustendynamik, FriedrichAlexander-Universität Erlangen-Nürnberg, Schlossgarten 5, 91054 Erlangen, Germany

3 Lindenring 6, 29352 Adelheidsdorf, Germany

4 Department of Earth and Environmental Sciences, University of Iowa, 121 Trowbridge Hall, Iowa City, IA 52242, USA

5 Beverveien 16, 9017 Troms $\varnothing$, Norway

6 Geological Survey of Canada, 615 Booth Street, Ottawa, ON K1A 0E9, Canada 
Keywords Ellesmerian fold-and-thrust belt - Eurekan deformation - Canadian Arctic Archipelago - Ellesmere Island · North Greenland · Spitsbergen

\section{Introduction}

The tectonic map of the Ellesmerian and Eurekan deformation belts on Svalbard, North Greenland and the Queen Elizabeth Islands (Fig. 1) is based on the literature and field work during the Hamburg and Münster Spitsbergen Expeditions (Germany) between 1985 and 1997 and results from the CASE program (Circum-Arctic Structural Events) of the Federal Institute for Geosciences and Natural Resources (BGR, Germany). Since 1992, BGR has carried out a number of expeditions to Svalbard, North Greenland and Ellesmere Island in cooperation with the Norwegian Polar Institute (NP), the Geological Survey of Denmark and Greenland (GEUS), the Geological Survey of Canada
(GSC), and a number of universities and museum institutions. Major subject of CASE is the Cenozoic deformation in the Arctic and the opening of the Arctic Ocean. It has turned out, however, that for an understanding of the young processes during the final break-up of Laurasia it is also necessary to understand how Laurasia was formed. Therefore, investigations of the pre-Cenozoic sedimentary basins and major tectonic events, like the Ellesmerian and Caledonian orogenies, were included as a base for interpretations of the Cenozoic plate tectonic evolution.

The tectonic map presented here shows the German contribution to the Tectonic Map of the Arctic 1:5,000,000 (TeMAr) as part of the international project "Atlas of geological maps of Circumpolar Arctic at 1:5,000,000 scale". The compilation of TeMAr is organized by the A. P. Karpinsky Russian Geological Research Institute (VSEGEI) in St. Petersburg in cooperation with institutions in Canada, Denmark, Germany, Norway, Russia, Sweden, and USA. The compilation of the map is supported by the

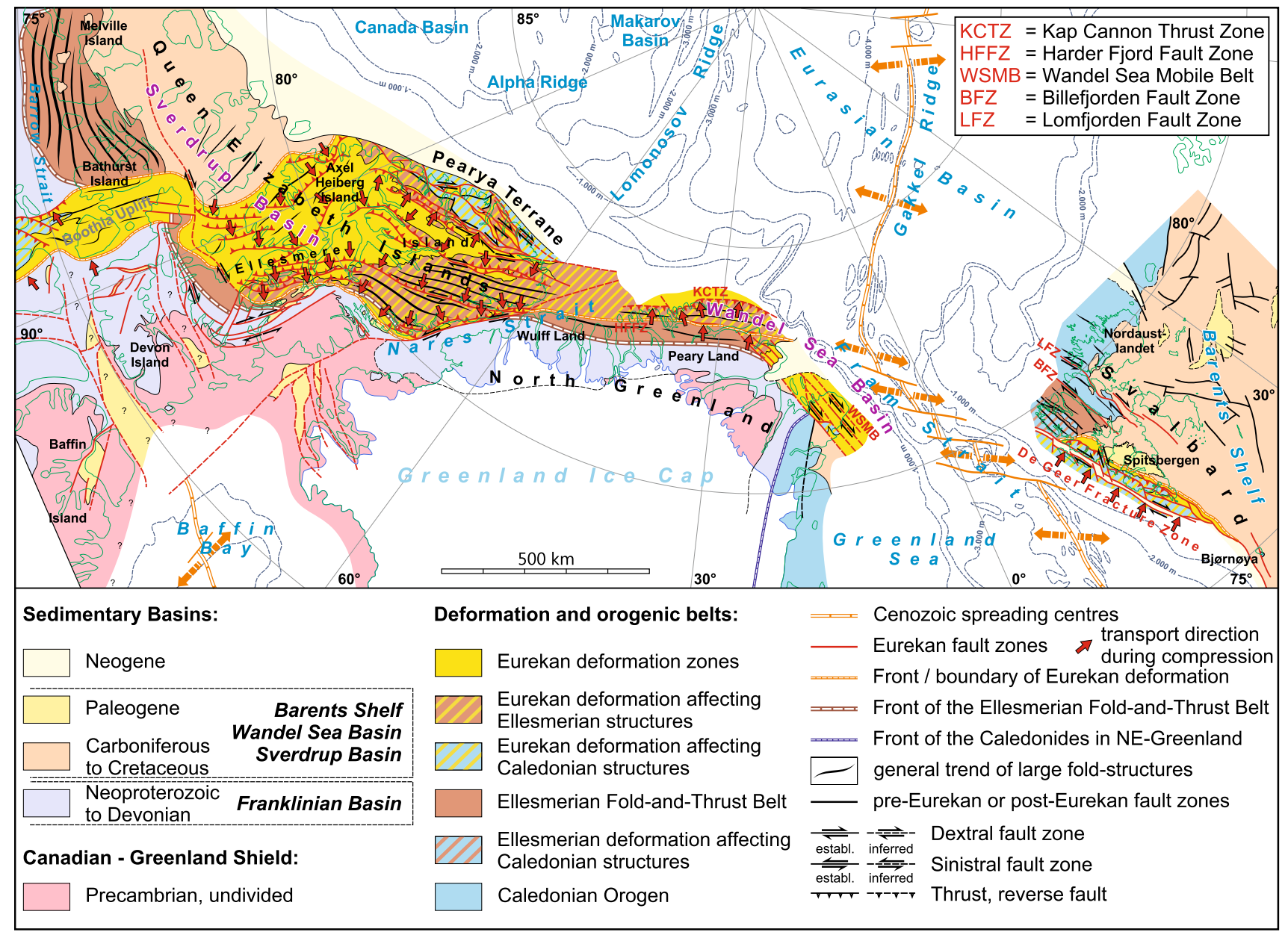

Fig. 1 Tectonic map of the Ellesmerian and Eurekan deformation belts on Svalbard, North Greenland, and the Queen Elizabeth Islands (Canadian Arctic). Redrawn and compiled from Okulitch [44], Håkansson et al. [21], Henriksen [30], Dallmann et al. [9, 10],
Harrison et al. [29], Piepjohn et al. [51, 52 submitted] and Dallmann [8]. The major Eurekan faults and thrust zones are drawn in red colour 
International Union of Geological Sciences (IUGS) and the Commission for the Geological Map of the World (CGMW) (UNESCO).

\section{Description of the tectonic map}

The tectonic map covers the areas of the present continental margins of the Barents Shelf and the north-eastern part of the North American margin including Greenland. Here, we briefly describe the main belts of deformation shown on the map. Concerning more detailed descriptions and plate tectonic interpretations, the reader is referred to, for example, Kristoffersen and Talwani [35], Talwani and Eldholm [62], Srivastava [58, 59], Vogt et al. [71], Menzies [43], Vink [70], Srivastava and Tapscott [60], Okulitch [44], Håkansson et al. [21], Trettin [67], Henriksen [30], Dallmann et al. [9, 10], Dallmann [8], Tessensohn and Piepjohn [64], CASE Team [7], Harrison et al. [29], and Piepjohn et al. [51, 52], submitted.

Along the continental margins, the following major geological features are exposed (compare Fig. 1):

- The pre-Ellesmerian Franklinian Basin in the Canadian Arctic and North Greenland (Neoproterozoic to Devonian) overlying the Achaean to Proterozoic basement of the Greenland-Canadian Shield.

- The Caledonian orogen along the east coast of Greenland and parts of it on Svalbard.

- The Devonian Old Red Sandstone Basin on Svalbard.

- The earliest Carboniferous Ellesmerian fold-and-thrust belt on the Queen Elizabeth Islands, North Greenland and Svalbard, which has affected the Franklinian Basin at the north margin of North America and the Caledonian structures and the Old Red Sandstone on Svalbard (Svalbardian deformation).

- The large post-Ellesmerian sedimentary basins, overlying the structures of the Ellesmerian fold-and-thrust belt, range in age from Early Carboniferous through Lower Cretaceous (Svalbard) and Upper Cretaceous (Sverdrup Basin in the Canadian Arctic and Wandel Sea Basin in North Greenland) to Paleogene.

- The deformation zones of the Eurekan deformation at the west margin of Svalbard (West Spitsbergen fold-and-thrust belt), North Greenland, and Queen Elizabeth Islands.

\section{Ellesmerian fold-and-thrust belt}

The Ellesmerian fold-and-thrust belt is exposed over a length of more than $3000 \mathrm{~km}$ from Melville Island in the west across Ellesmere Island and North Greenland towards
Spitsbergen on the European side of Fram Strait in the east (Fig. 1).

In the Canadian Arctic, Ellesmerian structures have affected the northern part of the Neoproterozoic to Devonian Franklinian Basin (e.g. [31, 53, 55, 56, 66, 67, 69]). The dominant structures are large-scale anticlines and synclines [41, 53], which are exposed on Melville Island, Bathurst Island, and Ellesmere Island. The trend of the Ellesmerian structures is E-W in the western Queen Elizabeth Islands, turns into $\mathrm{N}-\mathrm{S}$ direction on southern Ellesmere Island and turns again into a NE-SW direction on north-east Ellesmere Island, where the structures are truncated by the Wegener Fault along Nares Strait.

On Ellesmere Island, a number of SE-directed reverse faults have been developed during the Ellesmerian deformation as well [28, 53]. The most important high-angle thrust zone comprises the Petersen Bay and Mount Rawlinson faults in the north. It represents the boundary between the Franklinian Basin of Laurentia and the Pearya Terrane [13, 34, 51]. As the fold structures and the accompanying cleavage are subvertical, the general tectonic Ellesmerian transport direction is difficult to determine. SE-directed reverse faults on Ellesmere Island, however, indicate south and south-east transport directions towards the Canadian Shield. The Ellesmerian fold-andthrust belt is probably underlain by a deep-seated largescale detachment [28, 53]. The southern front of the Ellesmerian deformation in the Canadian Arctic is located north of Barrow Strait, in the south part of Ellesmere Island and north of the Inglefield Uplift. In large parts of the northern Queen Elizabeth Islands, Ellesmerian structures probably exist but are overlain by sedimentary rocks of the Sverdrup Basin.

In North Greenland, the Ellesmerian deformation has affected the northern part of the Franklinian Basin (Fig. 1). The trend of the structures is dominantly E-W. In contrast to the upright folds in the Canadian Arctic, the kilometrescale fold structures are N-vergent in the northern part and S-vergent in the southern part of the fold belt [55]. Three tectonometamorphic zones can be distinguished, which are characterized by a northward increase in deformation and metamorphic grade (e.g. [11, 12, 56]). Like on Ellesmere Island, the fold belt in North Greenland is underlain by a large-scale detachment [55]. The southern margin of the Ellesmerian fold-and-thrust belt in North Greenland is located from Wulff Land in the west to Peary Land in the east.

On Spitsbergen, Ellesmerian deformation was defined as the Late Devonian Svalbardian Folding by Vogt [72, 73]. Especially in the north-west of Spitsbergen, several kilometres-thick deposits of the $70 \mathrm{~km}$ wide and 160-km-long Old Red Sandstone Basin have been affected by the Ellesmerian deformation (e.g. [16, 17, 32, 38, 47, 49, 72]). 
In contrast to the extent of deformation along the North American margin, the Ellesmerian structures are concentrated in three narrow fold-and-thrust zones [48] dominated by either kink fold-like geometries or a combination of kmscale, west-vergent fold structures with corresponding west-directed thrust and reverse faults.

Outside the Old Red Sandstone Basin, the Caledonian basement at the west coast of NW-Spitsbergen was affected by west-directed Ellesmerian thrusting as well [47, 48]. Based on these observations, it can be assumed that a large Ellesmerian detachment exists within the Caledonian basement underneath the Old Red Sandstone Basin of NWSpitsbergen [47, 48].

The formation of the Ellesmerian fold-and-thrust belt was probably related to the approach of the Pearya Terrane and Svalbard from the north and collision with the Franklinian Basin of Laurentia. Bjørnerud and Bradley [4] suggested that the North American (Laurentian) crust was subducted northwards beneath Pearya. The approach of Pearya/Svalbard towards Laurentia was probably accompanied by sinistral strike-slip movements in Spitsbergen and Pearya in pre-Late Devonian time (e.g. [40, 42, 68]). However, the main stage of the Ellesmerian deformation coincides with the final docking of the Pearya Terrane/ Spitsbergen and Laurentia most likely in Tournaisian time and was dominated by orthogonal compression [33, 34, $51]$.

\section{Post-Ellesmerian and pre-Eurekan sedimentary basins}

The Ellesmerian deformation was followed by the formation of large sedimentary basins (e.g. [8, 12, 14, 45, 65]). The Sverdrup Basin in the north of the Canadian Arctic Archipelago, the Wandel Sea Basin in North Greenland and the sedimentary basin on Spitsbergen (Fig. 1) are characterized by a similar basin development and the deposition of comparable sedimentary units in all three areas. The Carboniferous was dominated by the deposition of clastic red beds and evaporites, which turned into carbonates and cherts in Late Carboniferous/Permian times. The Mesozoic was dominated by the deposition of finegrained clastic sediments.

\section{Eurekan deformation}

The Eurekan deformation in the American and European Arctic is characterized by the development of different systems of local fold-and-thrust belts and hundreds-ofkilometres long distinct thrust zones and strike-slip fault zones (Fig. 1) (compare [52] submitted). There are no general Eurekan trends or kinematics throughout the entire, almost $2500 \mathrm{~km}$ long and up to $400 \mathrm{~km}$ wide area along the north margin of North America and the west margin of Barents Shelf, which was affected by the Cenozoic deformation. In most areas, the Eurekan deformation has reactivated and overprinted the structures of the Ellesmerian orogen except for the western Queen Elizabeth Islands, Northeast Greenland, and the west coast of Spitsbergen.

In the Canadian Arctic, the Eurekan structures are characterized by extreme curvatures of the trends (Fig. 1) and different kinematics. From an E-W trend in southern Ellesmere Island, they turn into a N-S direction and further into a NE-SW direction north of the Inglefield Uplift (compare, e.g. [44, 52] submitted). In many areas, thrust faults turn into strike-slip faults. Often, Eurekan strike-slip faults have been reactivated as thrust faults in a later stage of the Eurekan deformation or vice versa. This points to at least two stages of Eurekan deformation. West of Inglefield Uplift, the transport direction of the compressional stage of the Eurekan deformation is towards the east, on north-east Ellesmere Island predominantly towards the south-east. The areas near the North American continental margin (Pearya) are dominated by sinistral and dextral strike-slip fault zones parallel to the continental margin [51].

West of Axel Heiberg Island, the Eurekan deformation dies out over a short distance. There, the Sverdrup Basin deposits are not affected by Eurekan compression. Until now, it is unknown whether dextral strike-slip faulting continues westwards in the western Queen Elizabeth Islands. Another open question is related to the formation of the N-S trending Boothia Uplift. It might represent a Eurekan compressional structure caused by a general dextral tectonic regime.

In North and Northeast Greenland, the Eurekan deformation is concentrated along three major fault zones (Fig. 1) (e.g. [57] and references therein; [56]): the Kap Cannon Thrust Zone at the north coast, the Harder Fiord Fault Zone north of Peary Land, and the Wandel Sea Mobile Belt in eastern North Greenland. The two fault zones in North Greenland are dominated by orthogonal N-S compression. The Kap Cannon Thrust Zone carries kilometres-thick metasedimentary rocks northwards on top of sedimentary rocks of the Wandel Sea Basin [12, 23, 61] and the volcanosedimentary units of the Upper Cretaceous Kap Washington Group [5, 6, 18, 37, 54, 57]. The northwards increase in metamorphism in North Greenland mentioned above is probably related to thrusting of deep-seated Ellesmerian units upwards during the Eurekan deformation.

The long, linear Harder Fiord Fault Zone suggests important lateral displacements [15, 31]. Results of structural analyses at the fault zone, however, argue for a compressional tectonic regime with transport directions to the north as well [50]. 
The Wandel Sea Mobile Belt [21,22] consists of a number of NW-SE trending distinct fault zones, which were dominated by dextral transpression (e.g. [19, 46] and references therein). The fault zones are oriented parallel to the strikeslip faults at the Barents Shelf margin opposite Fram Strait, but until now, it is unknown how they are related to the late Eurekan stage of deformation at the west coast of Spitsbergen. Furthermore, studies by Manby and Lyberis [39] and Guarnieri [20] have pointed out an older (pre-Eocene) compressive deformation in the Wandel Sea Mobile Belt.

On Spitsbergen at the west margin of the Barents Shelf, structures of the Eurekan deformation are concentrated along the $300 \mathrm{~km}$ long, NNW-SSE trending West Spitsbergen fault-and-thrust belt (Fig. 1) [1-3, 8, 24-27, 36, 62]; CASE Team [7, 8, 63]. Except for the northernmost end of the fold belt, ENE-vergent, kilometre-scale fold structures, thrust faults, nappe stacks, and detachment faults indicate overall tectonic transports towards the ENE perpendicular to the present continental margin of Spitsbergen. In the eastern part of the fold belt, Carboniferous through Lower Cretaceous deposits were affected by the Eurekan deformation. In this area, the style is dominated by thin-skinned tectonics. Observations in the northern part of the fold belt have shown that the Caledonian basement is involved in the Eurekan shortening characterized by thickskinned tectonics. The compressional structures are truncated by NNW-SSE trending dextral strike-slip faults. Further eastwards, the Billefjorden and Lomfjorden fault zones were affected by dextral strike-slip tectonics as well, which can be related to a late stage of the Eurekan deformation and the initiation of the separation of the Barents Shelf from North Greenland along the De Geer Fracture Zone.

\section{Concluding remarks}

The tectonic map of the Ellesmerian and Eurekan deformation belts on Svalbard, North Greenland, and the Queen Elizabeth Islands shows the structures of two major deformation belts in the North American and European Arctic. These can be related to the beginning of the consolidation (Ellesmerian) and the break-up (Eurekan) of the Late Palaeozoic/Mesozoic northern continent Laurasia. The Ellesmerian deformation pre-dates the development and evolution of the large Carboniferous through Cretaceous sedimentary basins along the North American Margin (Sverdrup Basin and Wandel Sea Basin) and on the Barents Shelf, which were separated through the evolution of the Eocene Eurekan plate tectonic reconfiguration during the final break-up of Laurasia and the opening of the Eurasian Basin, Labrador Sea/Baffin Bay and the Norwegian/Greenland Seas. Within most areas, the structures of the Ellesmerian deformation have been re- activated or overprinted by intense thrust faulting, folding and strike-slip tectonics during the Eurekan deformation. As the amounts of displacements along the Eurekan strike-slip faults are unknown until now, a reconstruction of the pre-Eurekan plate tectonic configuration is still difficult. Therefore, the reconstruction of plate tectonic processes leading to the formation of the Ellesmerian fold-and-thrust belt and even the Caledonian and older orogens in this area is uncertain. The challenge for the future is to reconstruct and restore the positions of the involved plates before the Eurekan deformation in the Eocene.

Acknowledgments We would like to express our thanks to numerous colleagues in Europe and North America for their contributions in field work and sharing their knowledge and opinions in discussions. This was one essential base to compile such a tectonic map covering a wide area. Thanks also to both anonymous reviewers for comments, suggestions, and corrections that helped improve the manuscript.

\section{References}

1. Birkenmajer K (1972) Tertiary history of Spitsbergen and continental drift. Acta Geol Pol 22(2):200-218

2. Birkenmajer K (1972b) Alpine fold belt of Spitsbergen. International Geological Congress, 24. Session, 282-292

3. Birkenmajer K (1981) The Geology of Svalbard, the western part of the Barents Sea, and the continental margin of Scandinavia. In: Nairn AEM, Churkin M, Stehli FG (eds) The ocean basins and margins: The Arctic Ocean, vol 5. Plenum Press, New York, pp 265-329

4. Bjørnerud M, Bradley DC (1994) Silurian foredeep and accretionary prism in northern Ellesmere Island: implications for the nature of the Ellesmerian Orogeny. In: 1992 Proceedings of the First International Conference on Arctic Margins (ICAM-92; Anchorage, Alaska, September 2-4, 1992), OCS Study MMS 94-004, 129-133

5. Brown PE, Parsons I (1981) The Kap Washington Group volcanics. Rapp Grønl Geol Unders 106:65-68

6. Brown PE, Parsons I, Becker SM (1987) Peralkaline volcanicity in the Arctic basin - the Kap Washington volcanics, petrology and palaeotectonics. J Geol Soc London 144:707-715

7. CASE Team (2001) The evolution of the West Spitsbergen Foldand-Thrust Belt. In: Tessensohn F (ed) Intra-continental fold belts. CASE 1: West Spitsbergen, Polar Issue No. 7, Geologisches Jahrbuch, B 91, 733-773

8. Dallmann WK ed (2015) Geoscience Atlas of Svalbard. Norsk Polarinstitutt Rapportserie 148:175-223

9. Dallmann WK, Andresen A, Bergh SG, Maher HD Jr, Ohta Y (1993) Tertiary fold-and-thrust belt of Spitsbergen, Svalbard. Norsk Polarinstitutt Meddelelser 128:1-46

10. Dallmann WK, Ohta Y, Elvevold S, Blomeier D (2002) Bedrock map of Svalbard and Jan Mayen, scale 1:750,000. Norsk Polarinstitutt Temakart, Theme map No. 33

11. Dawes PR (1971) The North Greenland fold belt and environs. Bull Geol Soc Den 20:197-239

12. Dawes PR, Soper NJ (1973) Pre-quaternary history of North Greenland. In: Pitcher MG (ed) Arctic geology, vol 19. Memoirs of the American Association of Petroleum Geologists, Tulsa, pp $117-134$ 
13. Estrada S, Piepjohn K, Henjes-Kunst F, von Gosen W (2006) Geology, magmatism and structural evolution of the Yelverton Bay area, northern Ellesmere Island, Arctic Canada. Polarforschung 73(2/3):59-75

14. Frebold H (1935) Geologie von Spitzbergen, der Bäreninsel, des König Karl- und Franz-Joseph-Landes. In: Krenkel E (ed) Geologie der Erde. Gebrüder Borntraeger, Stuttgart, pp 1-195

15. Friderichsen JD, Bengaard H-J (1985) The North Greenland fold belt in eastern Nansen Land. Rapp Grønl Geol Unders 126:69-78

16. Friend PF (1961) The Devonian stratigraphy of north and central Vestspitsbergen. Proc Yorkshire Geol Soc 33:77-118

17. Friend PF, Heintz N, Moody-Stuart M (1966) New unit terms for the Devonian of Spitsbergen and a new stratigraphical scheme for the Wood Bay Formation. Norsk Polarinstitutt Årbok 1965:59-64

18. von Gosen W, Piepjohn K (1999) Evolution of the Kap Cannon Thrust Zone (north Greenland). Tectonics 18(6):1004-1026

19. von Gosen W, Piepjohn K (2003) Eurekan transpressive deformation in the Wandel Hav Mobile Belt (northeast Greenland). Tectonics. doi:10.1029/2001TC901040

20. Guarnieri P (2015) Pre-break-up palaeostress state along East Greenland margin. J Geol Soc. doi:10.1144/jgs2015-053

21. Håkansson E, Heinberg C, Stemmerik L (1991) Mesozoic and Cenozoic history of the Wandel Sea Basin area, North Greenland. In: Peel JS, Sønderholm M (eds) Sedimentary basins of North Greenland. vol 160. Rapport Grønlands geologiske Undersøgelse, pp $153-164$

22. Håkansson E, Pedersen SAS (1982) Late Paleozoic to Tertiary tectonic evolution of the continental margin in North Greenland. In: Embry AE, Balkwill HR (eds) Arctic geology and geophysics, vol 8. Memoirs of the Canadian Society of Petroleum Geologists, Canada, pp 331-348

23. Håkansson E, Stemmerik L (1984) Wandel Sea Basin-The North Greenland equivalent to Svalbard and the Barents Shelf. In: Spencer AM, Holter E, Johnson SO, Mørk A, Nysæther E, Somgstad P, Spinnangr A (eds) Petroleum Geology of the North European Margin. Norwegian Petroleum Society/Graham \& Trotman, London, pp 97-107

24. Harland WB (1969) Contribution of Spitsbergen to understanding of tectonic evolution of North Atlantic region, vol 12. Memoirs of the American Association of Petroleum Geologists, Tulsa, pp 817-851

25. Harland WB (1973) Mesozoic geology of Svalbard. In: Pitcher MG (ed) Arctic geology, vol 19. American Association of Petroleum Geologists Memoir, Tulsa, pp 135-148

26. Harland WB (1973) Tectonic evolution of Barents Shelf and related plates. In: Pitcher MG (ed) Arctic geology, vol 19. American Association of Petroleum Geologists Memoir, Tulksa, pp 599-608

27. Harland WB, Horsfield WT (1974) West Spitsbergen Orogen. In: Spencer AM (ed) Cenozoic orogenic belts, data for orogenic studies, vol 4. Geological Society of London Special Publications, London, pp 747-755

28. Harrison JC (2008) Regional variation in structural style, deformation kinematics, and summary of tectonic history, northeast Ellesmere Island. In: Mayr U (ed) Geology of northeast Ellesmere Island adjacent to Kane Basin and Nares Strait, Nunavut, vol 592. Geological Survey of Canada Bulletin, Canada, pp 245-284

29. Harrison JC, Brent TA, Oakey GN (2006) Sheet 1 of 2, Bedrock Geology, Nares Strait, scale 1:1,000,000. Bedrock geology of the Nares Strait region of Arctic Canada and Greenland, with explanatory text and GIS content. Geological Survey of Canada, Open File 5278

30. Henriksen N (1992) Geological Map of Greenland 1:500,000, Sheet 7 Nybøe Land, Sheet 8 Peary Land. Grønlands Geologiske Undersøgelse, 1-40
31. Higgins AK, Friderichsen JD, Soper NJ (1981) The North Greenland fold belt between central Johannes V. Jensen Land and eastern Nansen Land. vol 106. Rapport Grønlands Geologiske Undersøgelse, pp 35-45

32. Holtedahl O (1914) On the old red sandstone series of northwestern Spitsbergen. Congress Report, XIIth Session, International Geological Congress, pp 707-712

33. Klaper EM (1990) The mid-Paleozoic deformation in the Hazen fold belt, Ellesmere Island, Arctic Canada. Can J Earth Sci 27:1359-1370

34. Klaper EM (1992) The Paleozoic tectonic evolution of the northern edge of North America-a structural study of northern Ellesmere Island, Canadian Arctic Archipelago. Tectonics 11:854-870

35. Kristoffersen Y, Talwani M (1977) Extinct triple junction south of Greenland and the Tertiary motion of Greenland relative to North America. Geol Soc Am Bull 88:1037-1049

36. Lowell JD (1972) Spitsbergen Tertiary orogenic belt and the Spitsbergen fracture zone. Geol Soc Am Bull 83:3091-3102

37. Manby GM, Estrada S, Thirlwall M, Lyberis N, Baxter AN (1998) Geochemical and isotopic constraints on the age and origins of Kap Washington Group volcanic and related dykes of north Greenland. In: International Conference on Arctic Margins (ICAM III), abstracts, p 119

38. Manby GM, Lyberis N (1992) Tectonic evolution of the Devonian Basin of northern Svalbard. In: Dallmann WK, Andresen A, Krill A (eds) Post-Caledonian tectonic evolution of Svalbard. vol 72. Norsk Geologisk Tidsskrift, pp 7-19

39. Manby GM, Lyberis N (2000) Pre-ocean opening compression of the northwestern Atlantic Ocean margin: evidence from eastern North Greenland. J Geol Soc Lond 157:707-710

40. Manby GM, Lyberis N, Chorowicz J, Thiedig F (1994) PostCaledonian tectonics along the Billefjorden fault zone, Svalbard, and its implications for the Arctic region. Geol Soc Am Bull 105:201-216

41. Mayr U, Dewing K, Harrison C, Piepjohn K, Tessensohn F (2008) Regional geology, northeast Ellesmere Island. In: Mayr U (ed) Geology of northeast Ellesmere Island adjacent to Kane Basin and Nares Strait, Nunavut, vol 592. Geological Survey of Canada Bulletin, pp 15-20

42. McCann AJ (2000) Deformation of the Old Red Sandstone of NW Spitsbergen; links to the Ellesmerian and Caledonian orogenies. In: Friend PF, Williams BPJ (eds) New perspectives on the Old Red Sandstone, Special Publications, vol 180. Geological Society, London, pp 567-584

43. Menzies AW (1982) Crustal history and basin development of Baffin Bay. In: Dawes PR, Kerr JW (eds) Nares Strait and the drift of Greenland: a conflict in plate tectonics. Meddelelser om Grønland, Geoscience, 8, 295-312

44. Okulitch AV (1991) Geology of the Canadian Arctic Archipelago, Northwest Territories and North Greenland, scale 1:2,000,000. Figure 2 in: Trettin HP (ed), Geology of the Innuitian Orogen and Arctic Platform of Canada and Greenland. Geological Survey of Canada, 3

45. Orvin AK (1940) Outline of the geological history of Spitsbergen. Skrifter om Svalbard og Ishavet 78:1-57

46. Pedersen SAS, Håkansson E (2001) Kronprins Christan land orogeny. Deformational styles of the end Cretaceous transpressional mobile belt in eastern north Greenland. Polarforschung 69:117-130

47. Piepjohn K (1994) Tektonische Evolution der Devongräben (Old Red) in NW-Svalbard. Unpublished PhD thesis, University of Münster, 1-170

48. Piepjohn K (2000) The Svalbardian/Ellesmerian deformation of the Old Red Sandstone and the pre-Devonian basement in NWSpitsbergen (Svalbard). In: Friend PF, Williams BPJ (eds) New 
perspectives on the old red sandstone, vol 180. Geological Society London Special Publications, London, pp 585-601

49. Piepjohn K, Brinkmann L, Grewing A, Kerp H (2000) New data on the age of the uppermost ORS and the lowermost post-ORS strata in Dickson Land (Spitsbergen) and implications for the age of the Svalbardian deformation. In: Friend PF, Williams BPJ (eds) New perspectives on the old red sandstone, vol 180. Geological Society London Special Publications, London, pp 603-609

50. Piepjohn K, von Gosen W (2001) Polyphase deformation at the Harder Fjord Fault Zone (North Greenland). Geol Mag 138(4):407-434

51. Piepjohn K, von Gosen W, Läufer A, McClelland WC, Estrada S (2013) Ellesmerian and Eurekan fault tectonics at the northern margin of Ellesmere Island (Canadian High Arctic). German J Geosci 164(1):81-105

52. Piepjohn K, von Gosen W, Tessensohn F (2015) The Eurekan deformation in the Arctic-an outline. Geological Society of London Special Publications (submitted)

53. Piepjohn K, von Gosen W, Tessensohn F, Saalmann K (2008) Ellesmerian fold-and-thrust belt (northeast Ellesmere Island, Nunavut) and its Eurekan overprint. In: Mayr U (ed) Geology of northeast Ellesmere Island adjacent to Kane Basin and Nares Strait, Nunavut. vol 592. Geological Survey of Canada Bulletin, pp 285-303

54. Soper NJ, Dawes PR (1970) A section through the north Peary Land fold belt. Proc Geol Soc Lond 1662:60-61

55. Soper NJ, Higgins AK (1987) A shallow detachment beneath the North Greenland fold belt: implications for sedimentation and tectonics. Geol Mag 124(5):441-450

56. Soper NJ, Higgins AK (1991) Late cretaceous-early tertiary deformation, North Greenland. In: Trettin HP (ed) Chapter 16 in Geology of the Innuitian Orogen and Arctic Platform of Canada and Greenland. Geological Survey of Canada, Geology of Canada, 3, 461-465

57. Soper NJ, Dawes PR, Higgins AK (1982) Cretaceous-tertiary magmatic and tectonic events in North Greenland and the history of adjacent oceanic basins. In: Dawes PR, Kerr JW (eds) Nares Strait and the drift of Greenland: a conflict in plate tectonics. Meddelelser om Grønland, Geoscience, 8: 205-220

58. Srivastava SP (1978) Evolution of the Labrador Sea and its bearing on the early evolution of the North Atlantic. Geophys J R Astron Soc 52:313-357

59. Srivastava SP (1985) Evolution of the Eurasian Basin and its implications to the motion of Greenland along Nares Strait. Tectonophysics 114:29-53
60. Srivastava SP, Tapscott CR (1986) Plate kinematics of the North Atlantic. In: Vogt PR, Tucholke BE (eds) The Geology of North America. vol. M. The Western North Atlantic Region: Geological Society of America, 379-405

61. Stemmerik L, Worsley D (1989) Late Palaeozoic sequence correlations, North Greenland, Svalbard and the Barents Shelf. In: Collinson JD (ed) Correlation in hydrocarbon exploration. Graham \& Trotman, London, pp 99-111

62. Talwani M, Eldholm O (1977) Evolution of the NorwegianGreenland sea. Geol Soc Am Bull 88:969-999

63. Tessensohn $\mathrm{F}$ ed (2001) Intra-continental fold belts-CASE 1: West Spitsbergen, Polar Issue No. 7. Geologisches Jahrbuch B 91:1-773

64. Tessensohn F, Piepjohn K (2000) Eocene compressive deformation in Arctic Canada, north Greenland and Svalbard and its plate tectonic causes. Polarforschung 68:121-124

65. Thorsteinsson R, Tozer ET (1960) Summary account of structural history of the Canadian Arctic Archipelago since Precambrian time. Geological Survey of Canada, paper, 60-7:1-23

66. Thorsteinsson R, Tozer ET (1970) Geology of the Arctic Archipelago. In: Douglass RJW (ed) Geology and Economic Minerals of Canada. Geological Survey of Canada, Economic Geology Report 1:547-590

67. Trettin HP (1991a) Tectonic framework. In: Trettin HP (ed) Chapter 4 in Geology of the Innuitian orogen and Arctic platform of Canada and Greenland. Geological Survey of Canada 3:59-66

68. Trettin HP (1991b) Late Silurian-early Devonian deformation, metamorphism, and granitic plutonism, northern Ellesmere and Axel Heiberg islands. In: Trettin HP (ed) Chapter 12b in Geology of the Innuitian Orogen and Arctic Platform of Canada and Greenland. Geological Survey of Canada 3:295-301

69. Trettin HP, Balkwill HR (1979) Contributions to the tectonic history of the Innuitian Province, Arctic Canada. Can J Earth Sci 16:748-769

70. Vink GE (1982) Continental rifting and the implications for plate tectonic reconstructions. J Geophys Res 87:10677-10688

71. Vogt PR, Kovacs LC, Johnson GL, Feden RH (1979) The Eurasia Basin. Norsk Petroleumsforening, Norwegian Sea Symposium 1979, NSS 3:1-27

72. Vogt T (1928) Den norske fjellkjedes revolusjonshistorie. Nor Geol Tidsskr 10:97-115

73. Vogt T (1938) The stratigraphy and tectonics of the Old Red formations of Spitsbergen. In: Abstracts of the Proceedings of the Geological Society of London, 1343:88 